
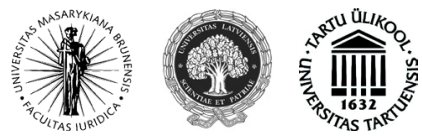

ISSN 1392-6195 (print) ISSN 2029-2058 (online) JURISPRUDENCIJA JURISPRUDENCE 2014, 21(1), p. 89-114.

\title{
BANKO PERTVARKYMO TEISINIAI MECHANIZMAI
}

\author{
Tomas Ambrasas \\ Mykolo Romerio universiteto Teisès fakulteto \\ Verslo teisès katedra \\ Ateities g. 20, LT-08303 Vilnius, Lietuva \\ Elektroninis paštas ambrasas@gmail.com \\ Pateikta $2014 \mathrm{~m}$. sausio 30 d., parengta spausdinti $2014 \mathrm{~m}$. kovo $13 \mathrm{~d}$.
}

doi:10.13165/JUR-14-21-1-05

\section{Ivadas}

Pasaulyje banko nemokumo teisinė kategorija suprantama kaip banko restruktūrizavimo procedūros (ịprastai tai suprantama kaip specialus finansų ịstaigų nemokumo režimas, teisès normų visuma, apimanti ir banko pertvarkymo teisines technikas, iskaitant, bet jomis neapsiribojant, derybas su galimais investuotojais, turto ir issipareigojimų perkèlimą, priežiūros institucijos sutikimą dẻl konkrečių restruktūrizavimo susitarimų, privačios banko informacijos atskleidimą tretiesiems asmenims ir pan.) ir (arba) banko likvidavimo procedūros (iprastai suprantama kaip teisès normų visuma, reguliuojanti banko bankroto procedūras, įskaitant, bet neapsiribojant, likvidatoriaus paskyrimą, likvidatoriaus teises ir pareigas, likvidatoriaus priežiūrą, kuri iprastai vykdoma kreditorių ir teismo, be kita ko, tai ir banko moratoriumas, t. y. banko veiklos sustabdymas, turto valdymas ir realizavimas, piniginių lèšu paskirstymas kreditoriams, banko veiklos pabaiga ir pan.) ${ }^{1}$.

1 International monetary fund and the World bank report. April 17, 2009. "An overview of the legal, institutional, and regulatory framework for bank insolvency", p. 7-8.

Lastra, R. M. Cross-border bank insolvency. Oxford university press. New York, 2011. p. 42-46.

Jurisprudencija/Jurisprudence

(C) Mykolo Romerio universitetas, 2014

(C) Mykolas Romeris University, 2014
ISSN 1392-6195 (print), ISSN 2029-2058 (online) http://www.mruni.eu/lt/mokslo_darbai/jurisprudencija/ http://www.mruni.eu/en/mokslo_darbai/jurisprudencija/ 
Prasidèjus pasaulinei finansų krizei bankų sektorius susidūrẻ su dideliais tiek ekonominiais, tiek teisiniais iššūkiais. Atsirado poreikis keisti teisini reguliavimą. Europos Sąungos (toliau - ES) įstatymų leidèjai suprato, jog gerai veikiančiai bendrajai rinkai reikia integruotos finansinio reguliavimo ir priežiūros sistemos. Tai yra esminis dalykas siekiant užtikrinti tų pačių aukštų standartų taikymą ES bankams, apsaugoti mokesčių mokètojus nuo žlungančių finansų îstaigų gelbejjimo ir užtikrinti îsikišimą laiku bei veiksmingiausią krizès sprendimą kilus problemoms. Šiuos tikslus ES įstatymų leidejjas siekia igyvendinti per Bankų sąjungos teisinị reguliavimą². Straipsnis nèra skirtas Bankų sąjungos teisès aktų analizei, tačiau pažymėtina, jog kuriant Bankų sąjungą šiuo metu siekiama sukurti naują, nuoseklią, integruotą finansinę sistemą visoje Europoje finansiniam stabilumui užtikrinti ir išlaidoms bankų žlugimo atveju sumažinti. Tuo siekiama vienodinti banko nemokumo teisę ir nenuoseklų teisinị reguliavimą ES valstybėse narèse ${ }^{3}$. Be kita ko, reikia pasakyti, jog šio tyrimo objekto kontekste Bankų sąjunga svarbi ir tuo, jog sudedamuosiuose Bankų sąjungos teisès aktuose pirmą kartą Europos istorijoje vienodinamas banko pertvarkymo teisinio mechanizmo institutas, kuris svarbus tuo, jog visuotinai yra suprantamas kaip ipprastinè bankroto bylos alternatyva ir priemonè, skirta žlungančiam bankui, kurio žlugimas sukeltų problemų viešajam interesui (keltų grèsmę finansiniam stabilumui, ypatingos svarbos banko funkcijoms ir indèlių, klientų turto ir viešųjų lèšų saugumui), restruktūrizuoti ar likviduoti ${ }^{4}$.

2 Bankų sąjungos sistemą, be bendro priežiūros mechanizmo ir naujos integruotos indèlių draudimo schemos, sudaro ir kredito ịstaigų pertvarkymo sistema, detaliai, be kita ko, reglamentuojanti ir bankų pertvarkymo teisinius mechanizmus. Šioje sistemoje numatyti ir valdžios institucijų igaliojimai perimti žlungančio banko turtą, akcijas, igaliojimai nurašyti ir konvertuoti banko skolą, nustatyti laikiną reikalavimų apmokejjimo moratoriumą, kreditoriams numatyti kompensavimo mechanizmai ir t. t. Bankų pertvarkymo ir gaivinimo direktyvoje nustatytas reguliavimas neišvengiamai ateityje bus inkorporuotas ir ị Lietuvos nacionalinę teisę, o Reglamentas dèl vieningo pertvarkymo mechanizmo taikomas tiesiogiai.

3 Pirmininkaudama Europos Sąjungos Tarybai Lietuva 2013 m. gruodžio 11 d. pasiekè vieną iš svarbiausių rezultatų Bankų sąjungos srityje - sutarimą su Europos Parlamentu dèl Bankų gaivinimo ir pertvarkymo direktyvos, kuria nustatomos bankų gelbejjimo taisyklès. Direktyva turès būti perkelta ị nacionalinę teisę ir reikalavimai ịsigalios nuo 2015 metų. Be to, kai kurie direktyvos elementai bus inkorporuoti ir ị bendrą pertvarkymo mechanizmą, dèl kurio 2013 m. gruodžio 18 d. Lietuva taip pat pasiekè bendrą susitarimą ES Taryboje. Iš esmès direktyva ir reglamentas, inter alia, reguliuoja ir banko pertvarkymo teisinius santykius ir suvienodins teisinę banko nemokumų reglamentavimo bazę Europoje.

4 Pasiūlymas dèl Europos Parlamento ir Tarybos direktyvos, kuria nustatoma kredito įstaigų ir investicinių i̇monių gaivinimo ir pertvarkymo sistema ir iš dalies keičiamos Tarybos direktyvos 77/91/EEB bei 82/891/EB, direktyvos 2001/24/EB, 2002/47/EB, 2004/25/EB, 2005/56/EB, 2007/36/EB bei 2011/35/EB ir Reglamentas (ES) Nr. 1093/2010; Pasiūlymas dèl Europos Parlamento ir Tarybos reglamento, kuriuo nustatomos kredito ịstaigų ir tam tikrų investicinių i̇monių pertvarkymo vienodos taisyklès ir vienoda procedūra, kiek tai susiję su bendru pertvarkymo mechanizmu ir Bendru bankų pertvarkymo fondu, ir kuriuo iš dalies keičiamas Europos Parlamento ir Tarybos reglamentas (ES) Nr. 1093/2010. Šiuose teisès aktuose, inter alia, ịtvir- 
Nors Lietuvos teisès aktai aiškiai apibrèžtos banko pertvarkymo sąvokos ir nepateikia, tačiau dar iki bankų sąjungos projekto svarstymo ES institucijose pirmą kartą Lietuvos istorijoje buvo panaudoti tam tikri banko pertvarkymo ir gyvybingumo atkūrimo teisiniai mechanizmai, kurie atitinkamai nèra moksliškai tirti bei analizuoti Lietuvoje. Šiuos mechanizmus ypatingai svarbu atskleisti moksline prasme, nes praktikoje banko tiesioginis likvidavimas (bankrotas), t. y. priešinga banko pertvarkymui teisinė procedūra, ne visada yra geriausia priemonė visuomenei, mokesčių mokètojams ir kreditoriams. Likvidavimo procedūrų trukmè, sąnaudos ir rezultatai ịprastai yra žalingi skolininkams ir kreditoriams (ilgai trunka, didesnès išlaidos administravimui ir teisinėms paslaugoms, didejja valstybės fiskalinės išlaidos, operatyviai neparduodamas daug kartų nuvertèja banko turtas, reikalingos sudètingos derybos ir susitarimai tarp kreditorių ir t. t.). Be to, visuomenejje banko likvidavimas (bankrotas) ir banko pertvarkymas vis dar yra painiojamos sąvokos, o šių procedūrų teisinis turinys suvokiamas miglotai. Lietuvos pozityviojoje teisejje šiuo metu yra ịtvirtintos tam tikros teisinès technikos, padedančios kovoti su banko mokumo problemomis: banko nacionalizavimas, banko turto, teisiu, sandoriu ir isipareigojimu perdavimas kitam bankui, banko turto atskyrimas, laikinos kreditu istaigos sukūrimas, banko verslo pardavimas. Visos šios priemonės padeda spręsti tam tikras nemokių bankų problemas, t. y. juos restruktūrizuoti ir (arba) pertvarkyti ${ }^{5}$. Taigi, būtina yra šiuos teisinius mechanizmus objektyviai ir moksliškai išnagrinèti, atskleisti jų pagrindinius principus ir teisines pasekmes, kylančias atitinkamus mechanizmus pritaikius. Tyrimo rezultatai kilo išanalizavus mokslinę literatūrą, kompetentingų institucijų studijas ir pranešimus, atlikus atitinkamų teisės aktų ir teismų praktikos analizę. Straipsnis yra parašytas Lietuvos teisès požiūriu.

Temos mokslinis naujumas reiškiasi iš esmès niekada nenagrinėta nemokaus banko pertvarkymo teisine kategorija Lietuvoje. Mokslinè tokio pobūdžio tyrimo problema, be kita ko, visa apimtimi susijusi su temos aktualumu ir naujumu.

Tyrimo objektas - banko pertvarkymo mechanizmų teisinis reglamentavimas ir taikymas Lietuvos Respublikoje. Tyrimo moksliné problema - kokie yra pagrindiniai banko pertvarkymo teisiniai mechanizmai pagal teisinị reguliavimą Lietuvoje ir

tinta bendra taisyklè, kad jeigu, institucijų vertinimu, nekyla grèsmès finansiniam stabilumui ir mokesčių mokètojams, ịprastai yra leidžiama bankui (ar jo dalims) žlugti ịprastu būdu.

5 Dèl terminologijos pasakytina, jog literatūroje aptinkamos tiek banko restruktūrizavimo (angl. bank restructuring) sąvokos: pvz., Rosa, M. Lastra knygoje „Cross-border bank insolvency“, tiek banko pertvarkymo sąvokos (angl. bank resolution), pvz., ši sąvoka įsivyravusi Banko pertvarkymo ir gaivinimo direktyvoje, Reglamente dèl vieningo pertvarkymo mechanizmo, arba vartojama ir viena, ir kita sąvoka, pvz., David, S. Hoelscherio knygoje „Bank restructuring and resolution". Autorius darbe daugiau vartoja banko pertvarkymo sąvoką (angl. resolution), remdamasis tuo, jog ši sąvoka modernesnè, būtent ši sąvoka ịsivyravusi jau priimtuose Bankų sąjungos teisès aktuose, ir šiek tiek platesnè, t. y. suprantama kaip bankų problemų sprendimų būdų, apimančių ir bankų pertvarkymo teisinius mechanizmus, visuma. Kita vertus, pažymètina, jog šios sąvokos pagal savo turinị iš esmès yra tapačios. 
kokios teisinės pasekmės kyla juos taikant. Tyrimo tikslas - ištirti ir atskleisti nemokaus banko pertvarkymo teisinius mechanizmus pagal Lietuvos teisę, supažindinti su pagrindiniais banko pertvarkymo mechanizmų veikimo principais ir tam tikrais ypatumais.

Tyrimo metodai. Loginis metodas taikytas darant pagrịstus surinktų faktų apibendrinimus, formuluojant tarpines ir galutines tyrimo išvadas. Sisteminés (dokumentu) analizés metodas taikytas siekiant sistemiškai ịvertinti egzistuojantị bankų teisinès aplinkos reguliavimą Lietuvoje, ịtvirtintą Lietuvos Respublikos teisės aktuose, juo nustatyta bankų ir nemokumo teisès normų sisteminis ryšys, darant pagrịstas prielaidas dèl konkrečios normos prasmès, atskleidžiant restruktūrizavimo mechanizmų teisinę prigimtị ir reikšmę banko nemokumo kontekste. Lingvistinis metodas prisidejjo prie tikrosios teisès normų prasmès, turinio ir ryšių su kitomis normomis atskleidimo, analizuojant tiriamus tekstus, remtasi gramatikos, sintaksès ir kitomis kalbos taisyklemis. Apibendrinimo metodas, kartu su loginiu, padejo nustatyti tiriamų teisinių instrumentų bendruosius, pagrindinius požymius ir savybes.

Tyrimo metodologines nuostatos - straipsnyje vyrauja hermeneutikos mokslinio pažinimo metodas. Banko nemokumo teisè, kaip ir banko restruktūrizavimo teisiniai mechanizmai, iš esmès grịsti interpretacijos ir supratimo teorija bei tyrimui būdingais kokybiniais metodais.

\section{Banko, kaip atskiros rūšies verslo subjekto, nemokumo ypatumai}

\subsection{Banko pertvarkymo mechanizmo samprata, pagrindiniai tikslai ir principai}

Siauruoju požiūriu banko pertvarkymas turi būti suprantamas kaip individualus, mokumo problemų turinčio banko veiklos pertvarkymas. Analizuojant plačiau pasakytina, kad bankas pertvarkomas pasirenkant tam tikrą banko pertvarkymo teisini mechanizmą. Mechanizmas parenkamas ad hoc pagrindais (mokslinëje literatūroje paplitęs angl. case-by-case terminas), todèl banko pertvarkymas yra ir tam tikrų pertvarkymo strategijų pasirinkimas, tam tikra banko finansinès veiklos įvertinimo procedūra. Iprastai ši veiksmą atlieka kompetentinga priežiūros institucija ${ }^{6}$.

6 Bankų priežiūros institucijos yra sukurtos tam, kad stebètų šalyje veikiančių bankų veiklą ir adekvačiai reaguotų ị bankų elgesị, sumažintų banko įsipareigojimų ir kapitalo rizikos lygị, prisiimtą banko valdymo organų ir valdytojų, pvz., netinkamas likvidumo ar kredito rizikos valdymas bei neadekvačios teisinès poveikio priemonès nusižengus vienam ar kitam teisès aktui, sumažintų banko nemokumo neigiamus padarinius ir reikalui esant pritaikytų atitinkamus bankų nemokumo teisinius mechanizmus. 
Mokslineje literatūroje banko pertvarkymas kartais dar suprantamas ir kaip banko pertvarkymo metodų visuma, užtikrinanti kiek įmanoma greitesnị piniginių lèšų prieinamumą indelininkams bei kitiems kreditoriams ${ }^{7}$. Bendra taisyklè yra ta, jog jeigu, priežiūros institucijų vertinimu, nekyla grèsmès finansiniam stabilumui ir mokesčių mokètojams, gali būti leidžiama bankui (ar jo atskiroms dalims) žlugti ir ịprastu būdu, todèl banko pertvarkymas yra ir ịprastinès bankroto bylos alternatyva, kurios pagrindinis tikslas - pašalinti nemokų banką iš finansų sistemos kartu išlaikant investuotojų ir visuomenės pasitikejimą bankų sektoriumi ${ }^{8}$. Atsižvelgiant $\mathfrak{i}$ tai, kad sutrikus bankų sistemos veiklai būtų pažeidžiami kone visų visuomenès narių interesai, taip pat ir jų nuosavybès teisè, bankų sistemos stabilumas ir patikimumas turètų būti laikomas visuomenès interesu, kurị valstybè, vykdydama savo funkcijas, yra konstituciškai ipareigota užtikrinti (Lietuvos Respublikos Konstitucijos 23 str. 1 d., 46 str. 3, 4 d.). Taigi, banko pertvarkymo tikslas - siekti kuo mažesnių neigiamų padarinių mokesčiu mokètojams ir visuomenei, pertvarkyti finansinių problemų turintị banką, tinkamai suvaldyti teisines ir ekonomines rizikas, kylančias dèl „blogų“ banko paskolų, netinkamai suformuotų specialiųjų atidejjimų, netinkamai ịvertinto nemokaus banko turto ir pan.

Banko pertvarkymas susideda iš tam tikrų teisinių elementų: 1) priežiūros institucijai reikia ịvertinti ir nustatyti banko finansinę būklę, t. y. îsipareigojimų ir turto santykị bei likvidumą, padarytus teisès aktų pažeidimus, t. y. priežiūros institucijos nustatytų reikalavimų nesilaikymas, ex ante panaudoti ịstatymuose numatytas visas iprastas poveikio priemones, taip pat ịvertinti banko išskaidymo finansinius nuostolius, pertikrinti esamą banko finansinio turto masę, suformuotus atidejjimus, patikrinti kapitalo pakankamumo reikalavimus ir tada priimti sprendimą dèl banko pertvarkymo (paremta tuo, jog priežiūros institucijos duomenys apie konkretų banką gali būti pasenę ir ịprastai neatspindi realios ekonominès situacijos, todèl duomenis reikia atnaujinti). 2) Priežiūros institucijai reikia ịvertinti banko akcininkų struktūrą (privatūs ar viešieji juridiniai asmenys, reziduojantys Lietuvoje ar užsienio valstybėse, koncentruota ar išskaidyta akcininkų struktūra ir pan.). Tai suponuoja tam tikrus kriterijus bei banko pertvarkymo apimtis ir padeda preliminariai susidaryti bendrą finansinių sunkumų turinčio banko vaizdą ir, ịvertinus visas aplinkybes, preliminariai nuspręsti, ar galimas išankstinis viešas palaikymas.9. 3) Reikia pasirinkti konkretų ir tinkamiausią pertvarkymo mechanizmą: tiesioginis likvidavimas; indèlių perkèlimas ị kitą banką; laikinojo banko sukūrimas (angl. bridge bank), kai dalis nemokaus banko turto yra perkeliama ị kitą „sveiką" banką, o blogoji banko turto dalis iprastai realizuojama per likvidavimo procedūras; akcijų perkèlimas įskaitant, bet juo

Hoelscher, David S. Bank restructuring and resolution. İžanga. New York: Palgrave Macmillan, 2006.

$8 \quad$ Ibid.

9 Hoelscher, David S., supra note 7, p. 98-101. 
neapsiribojant, akcijų paėmimą visuomenės poreikiams (ši opcija ịprastai naudojama kaip prielaida kitiems pertvarkymo mechanizmams taikyti). 4) Sprendimas dèl banko pertvarkymo mechanizmų taikymo turi būti priimtas labai operatyviai. Sudaromas detalizuotas veiksmų planas, privaloma vadovautis viešumo ir skaidrumo principais. Reikia ịvertinti ir tai, ar bandant banką išgelbèti nebus patirta didesnių išlaidų kreditorių sąskaita nei kad tiesioginio likvidavimo atveju. Taigi, keliant klausimą, ar bankas sugebès toliau sèkmingai funkcionuoti, restruktūrizavimo galimybę reikia įvertinti ne ilgalaikeje, o trumpalaikeje perspektyvoje. Šis elementas apima ir politinius sprendimus, kaip antai sprendimus dèl finansinès naštos pasidalinimo, dèl rinkos ịvertinimo, dèl „užkrato “ tikimybès visai šalies bankų sistemai ir pan. 5) Banko pertvarkymo mechanizmai visais atvejais turi būti pagrịsti viešų ir privačių interesų derinimo principu: i) banko problemų sprendimas visų pirma savininkų, akcininkų ir kreditorių pinigais, vadinamuoju bail-in būdu (ịprastai tai skolų nurašymo priemonès arba, kitaip sakant, tai kapitalo ir ịsipareigojimų nurašymas ir / arba jų dalies pavertimas akciniu kapitalu); ii) bail-out principas, kai bankai yra gelbejjami valstybès lěšomis arba „išoriniais“ pinigais. Be to, pagal egzistuojančią pertvarkymo sistemą kiekvienoje valstybèje nustatomi tam tikri nuostolių paskirstymo principai, kurių reikètų laikytis atitinkamai pagal kiekvienos šalies nemokumo režimą. Šie principai yra: a) visi nuostoliai pirmiausia paskirstomi akcininkams, o tada kreditoriams ir b) tos pačios klasès kreditoriams gali būti taikomas skirtingas požiūris, jei tai pagrịsta viešuoju interesu ir visų pirma siekiant paremti finansinį stabilumą. Šie principai taikomi visoms banko pertvarkymo priemonèms. Reikia pažymèti ir tai, jog gelbejjimo privačiomis lèšomis priemonès atžvilgiu atitinkamoje teisinejje sistemoje išsamiau nustatomas reikalavimų tenkinimo eiliškumas. Prieš pasirenkant tam tikrą banko pertvarkymo mechanizmą svarbu yra įvertinti, kas prisiims banko nemokumo nuostolius ir kas bus apsaugotas nuo nuostolių, iš esmès tai yra kreditorių reikalavimų tenkinimo eilès ir reikalavimų pirmenybès klausimas.

Sistemiškai analizuodami Lietuvos Respublikos finansinio tvarumo ịstatymą galime teigti, jog iš esmès banko pertvarkymo mechanizmų tikslas Lietuvoje yra stiprinti bankų sistemos finansinį tvarumą, siekiant apsaugoti svarbius visuomenès interesus ${ }^{10}$. Finansinio stabilumo stiprinimo priemones (tarp jų ir banko pertvarkymo teisinius mechanizmus) galima taikyti po vieną arba kelias iš karto ${ }^{11}$. Be to, labai svarbu, kad restruktūrizuojant banką yra nustatomi tam tikri nuostolių paskirstymo principai (pvz., visi nuostoliai pirmiausia paskirstomi akcininkams, o tada kreditoriams $\left.^{12}\right)$.

10 Lietuvos Respublikos finansinio tvarumo įstatymas. Valstybès žinios. 2009, Nr. 93-3985. 1 straipsnis.

11 Ibid., 2 straipsnio 4 dalis.

12 Lietuvos Respublikos bankų ịstatymas. Valstybès žinios. 2004, Nr. 54-183. 87 straipsnio 7 dalis. 


\subsection{Banko nemokumas ir lex specialis. Pagrindinès banko nemokumo priežastys ir padariniai}

Visuotinai pripažįstama, jog bendrųjų nemokumo teisès normų nepakanka tinkamai reguliuoti mokumo problemų turintị banką ${ }^{13}$. Norint objektyviai ịvertinti pertvarkymo teisinius mechanizmus visų pirma reikia įvertinti priežastis, dèl kurių banko pertvarkymui nepakanka bendrų nemokumo teisès normų, taikomų ịprastoms įmonėms. Iš esmės taip yra dèl specifinès bankų veiklos bei dẻl kylančios sisteminès rizikos. Bankinė veikla, kaip ir kitos verslo rūšys, yra susijusi su rizikos prisièmimu, tačiau tai neišvengiamai daro didžiulę ịtaką visai šalies finansų sistemai. Kartais dèl nepamatuotos rizikos tam tikras bankas susiduria su laikinomis arba ilgalaikèmis finansinėmis problemomis. Tokiu atveju kompetentingai priežiūros institucijai reikia spręsti nemokaus banko problemas, panaudojant tam tikras banko gelbejjimo priemones, t. y. banko pertvarkymo teisinius mechanizmus. Taigi kokios priežastys lemia, kad banko nemokumas reguliuojamas skirtingai nei ịprastų verslo subjektų nemokumas? Pirma, banko nemokumo teisè pasaulyje daugiausia reguliuojama lex specialis, o ne lex generalis teisès normomis ${ }^{14}$. Be to, bankų nemokumo ypatumus ir problematiką lemia didesnis nei ịprastų verslo subjektų nemokumo atveju viešas interesas ${ }^{15}$, didesnis kreditorių sąrašas, plati banko veiklos specifika ir plati banko veikimo jurisdikcija (iprastai bankai veikia tarpvalstybiniu lygiu (angl. cross-border), didesnè bendra turto masè, sudètingesnès banko sandorių finansinès operacijos bei apimtys, platus ir labai specifiškas banko produktų sąrašas, ypatinga indėlininkų teisių apsaugos sistema, išskirtiniai teisiniai mechanizmai, reguliuojantys banko restruktūrizavimą. Pažymètina, jog nemokumo teisinès rizikos turi neabejotiną ịtaką ir ekonominėms valstybės rizikoms, kaip antai fiskalinei politikai, finansų stabilumui ir pan. Antra, bankui tapus nemokiam patiriamos išlaidos yra kur kas didesnès nei iprasto verslo subjekto nemokumo atveju (žlugus ne finansų įstaigai). Pavyzdžiui, kai kurių mokslininkų skaičiavimais, banko turto nuostoliai tiesioginio likvidavimo atveju yra labai reikšmingi ir siekia apie 30 proc. realios banko turto vertès, o tai gerokai didesni skaičiai nei bankrutavus ịprastam verslo subjektui, t. y. ne finansų įstaigai

13 Lastra, R. M., supra note 1, p. IX.

14 Ibid., p. 34-37.

15 LAT 2012 m. vasario 20 d. nutartis civilinejje byloje Nr. 3K-3-58/2012. Kasacinis teismas pažymëjo, kad finansų sektorius, kurio reikšmingą dalị Lietuvoje sudaro bankų sektorius, priskirtinas prie vieno jautriausių sektorių, o situacija jame gali turèti didelès įtakos šalies ekonomikai, gyventojų ir ūkio subjektų pasitikèjimui šalies finansų sistema, šios sistemos tvarumui, todèl būtina užtikrinti tinkamų ir laiku igyvendinamų finansų sistemos stabilumo stiprinimo priemonių panaudojimo galimybes. Šios įstatymų nuostatos rodo, kad finansų sistemos stabilumas yra viešasis interesas, o griežtas paskolos sąlygų laikymasis, atsižvelgiant ị kreditavimo verslo specifiką, turi esminę reikšmę. 
(nuo 10 iki 20 proc. turto vertès) $)^{16}$. Panašią išvadą galime padaryti analizuodami ir bankrutavusio banko „Snoras“ atveji ${ }^{17}$. Pažymètina, kad dažniausiai vien tik administravimo ir teisinès išlaidos, taikant tiesiogines likvidavimo procedūras, sudaro apie 10 proc. žlugusio banko bendros turto vertès ${ }^{18}$. Be to, bankų bankroto procesai (tiesioginis likvidavimas) trunka labai ilgai, ju metu iki turto realizavimo momento gerokai sumažèja turto vertè. Trečia, kai bankas de facto tampa nemokus ${ }^{19}$ iš esmés egzistuoja keturi pagrindiniai nemokaus banko problemų sprendimo ir pertvarkymo būdai (ang. resolution): i) nemokus bankas gali tiesiog bankrutuoti (taikomos tiesioginès likvidavimo procedūros), ii) bankas parduotas kaip verslas (angl. merger and aquisitions), iii) ịkurta laikinoji kredito įstaiga, iv) turtas atskirtas, t. y. parduotas dalimis, pavyzdžiui, turto, teisių, sandorių ir ịsipareigojimų perdavimas kitam bankui (angl. purchase and assumption agreement), v) bankas nacionalizuotas ${ }^{20}$. Tai kur kas platesnis teisinių variacijų spektras nei iprasto verslo subjekto pertvarkymo atveju. Ketvirta, banko nemokumo ypatumus lemia ir itin didelis ir specifinis banko nemokumo priežasčių spektras. Iliustruojant paminètinos kelios aktualiausios priežastys Europos Sąjungos kontekste: netvarūs verslo modeliai, pagrįsti pernelyg dideliu isiskolinimu ir per didele priklausomybe nuo trumpalaikio didmeninio finansavimo, per didelis darbuotojų skaičius ar pernelyg išpüsta banko struktüra, silpna visų rizikos rüšiu valdymo sistema, nepakankamas vidaus audito tarnybos darbas, netinkamo operaciju atvaizdavimo apskaitoje atvejai, paskolos susijusiems su akcininkais asmenims, tyčiniai nusikalstami veiksmai ir t. t. ${ }^{21}$ Penkta, akcentuotina, jog pastaroji finansu krizè lèmé daug bankų nemokumo atvejų, kurie susidūrè ir su kapitalo nepakankamumu $^{22}$, o tai buvo viena svarbiausių banko nemokumo priežasčių. Kapitalo reika-

16 Marinc, M.; Vlahu, R. The Economics of Bank Bankruptcy law. Berlynas: Springer - Verlag Berlin Heidelberg, 2012, p. 42-44.

17 AB banko „Snoras“ bankroto administratoriaus pateiktos veiklos ataskaitos rodo, jog vien tik per trijų mėnesių laikotarpi, pvz., laikotarpis iki 2013 m. birželio 30 d., ir jame atliktų mokèjimų suma sudaro $16,9 \mathrm{mln}$. Lt, įskaitant $6,4 \mathrm{mln}$. Lt veiklos sąnaudas, 9,4 $\mathrm{mln}$. Lt (su PVM) išmokas konsultantams ir t. t. [žiūrèta 2014-01-02]. <http://www.snoras.com/files/tinymce/ files/LT\%207\%204\%20-\%20Annual\%20report\%20-\%20FINAL.pdf>.

18 Marinc, M.; Vlahu, R., supra note 8, p. 42-44.

19 Lietuvos Respublikos bankų įstatymas, supra not, 12, 84 straipsnio 1 dalis.

Sąlygas, kurioms esant bankas gali būti pripažistamas nemokiu, ir banko nemokumo apskaičiavimo ir ịvertinimo tvarką nustato priežiūros institucijos teisès aktai. Be kita ko, finansų ịstaiga pagal Lietuvos Respublikos finansų ịstaigų nuostatas privalo būti visada pasirengusi vykdyti savo ịsipareigojimus pagal pirmą kliento pareikalavimą (likvidumas) ir ịvykdyti visus savo ịsipareigojimus (mokumas).

20 Marinc, M.; Vlahu, R., supra note 8, p. 42-44.

21 Europos Komisijos informacinis pranešimas, Briuselis, 2012 m. birželio 22 d., MEMO/12/478 [interaktyvus]. [žiūrèta 2013-03-23]. <http://europa.eu/rapid/press-release_MEMO-12-478_ lt.htm\#PR_metaPressRelease_bottom>.

22 Užklupus krizei bankų sektoriaus ịstaigų turimas kapitalas buvo nepakankamas tiek kiekybès, tiek kokybès požiūriu, todèl prireikè precedento neturinčios nacionalinių valdžios institucijų 
lavimai skiriasi nuo ịprastų verslo subjektų. Be to, ịprastai bankas netampa nemokus per naktį ${ }^{23}$. Tai vyksta laipsniškai pažeidžiant teisės aktų reikalavimus, kai bankas palaipsniui pradeda neatitikti keliamų kapitalo reikalavimų, o tai automatiškai reikalauja atitinkamų priežiūros institucijos veiksmų ${ }^{24}$. Jeigu banko akcininkai nepadidina banko kapitalo iki reikalaujamos normos ${ }^{25}$ (arba tai daro daugiau formos, o ne turinio prasme) - tokiu atveju priežiūros institucija, siekdama išlaikyti finansų sistemos stabilumą bei pasitikejjimą, pradeda ieškoti nemokaus banko problemų sprendimo būdo (pvz., „blogų paskolų“ problemų sprendimas ${ }^{26}$ ), t. y. turi ieškoti tam tikrų teisinių mechanizmų, galinčių pašalinti mokumo problemų turintị banką iš civilinès apyvartos efektyviausiu būdu.

Galiausiai, nagrinejjant banko pertvarkymo teisinę kategoriją, reikia aptarti ir esminius banko nemokumo teisinius padarinius, kurie kyla dèl specifinių banko nemokumo priežasčių. Lietuvos Respublikos įmonių restruktūrizavimo įstatymo normos netaikomos expressis verbis banko pertvarkymo atveju, nes i) iš esmès neįmanoma sulyginti ịprastų verslo subjektų (bankai išimtinai verčiasi tiktai finansinių ir su tuo susijusių paslaugų teikimu ${ }^{27}$ ) ir bankų reikšmės finansų sistemai. Bankai įmonėms, piliečiams ir visai ekonomikai teikia gyvybiškai svarbias paslaugas. Jų veikla iš esmès grindžiama pasitikejjimu ir jie gali greitai tapti negyvybingi, jei jų klientai ir sandorio šalys nebetikètų, kad jie ịvykdys ịsipareigojimus. ii) Dėl kredito ịstaigų tarpusavio ryšių masto kyla sisteminès krizès, kai vieno banko problemos tampa visos sistemos

paramos. Pateikusi pasiūlymą dèl bankų kapitalo poreikio Europos Komisija Europos Sąjungoje pradejo igyvendinti naujus tarptautinius banko kapitalui taikomus standartus, dèl kurių susitarta G20 lygmeniu (vadinamasis susitarimas „Bazelis III“). Šioje srityje Europa rodo pavyzdị - šias taisykles ji taiko daugiau kaip 8 tūkst. bankų, kurie valdo 53 proc. pasaulio turto. Šiuo metu Komisijos pasiūlymai svarstomi Taryboje ir Europos Parlamente. Šaltinis: Europos komisijos informacinis pranešimas, Briuselis, $2012 \mathrm{~m}$. birželio 22 d., MEMO/12/478, supra note 21 .

23 Hoelscher, David S., supra note 7, p. 97.

24 Lietuvos banko ataskaita apie AB „Snoras“ bankroto procesą [interaktyvus]. [žiūrèta 2013-0210]. <http://www.lb.lt/seimo_posedyje_ab_banko_snoras_bankroto_proceso_apzvalga_1>. Neribojamos rizikos, banko kapitalas nepalaiko reikalaujamo kapitalo lygio, neribojamos palūkanos, mokamos neprofesionaliems rinkos dalyviams ir pan. Pažeidimai nesilaikant šių kriterijų atitinkamai susiję su priežiūros institucijos taikomomis poveikio priemonemis bankui.

25 Pagal Lietuvos Respublikos bankų ịstatymo 41 straipsnio 1 dalį banko ịstatinis kapitalas sudaromas, didinamas ir mažinamas Akcinių bendrovių ịstatymo nustatyta tvarka, jeigu Bankų istatymas nenustato kitaip.

26 Campbell, A. Bank insolvency and the problem of nonperforming loans. Journal of Banking regulation, 2007, UK, p. 25-45. Didejjant blogų paskolų skaičiui mažèja kredito davejo gaunamų iš periodinių kreditų grąžinimo mokèjimu lèšų srautai, todèl kredito davejas (bankas) gali susidurti su lèšu trūkumu ir siekdamas tinkamai vykdyti savo ịsipareigojimus (pvz., grąžinti indèlininkams lèšas) būti priverstas ieškoti papildomų finansinių resursų, nes priešingu atveju galètų iškilti paties banko nemokumo rizika.

27 Lietuvos Respublikos bankų i̦statymas, supra note 12, 4 straipsnis. 
problemomis (kitaip skaičiuojama ir matuojama rizika, kas iš esmès skiriasi nuo įmonių restruktūrizavimo įstatymo nuostatų. iii) İmonès restruktūrizavimo byla iškeliama teisme, tuo tarpu banko restruktūrizavimo teisiniai mechanizmai gali būti pritaikyti išimtinai priežiūros institucijos sprendimu (be teismo leidimo). iv) Dèl pareiškimo iškelti ịmonès restruktūrizavimo bylą teismas priima nutartị, banko restruktūrizavimo atveju priimami priežiūros institucijos sprendimai, t. y. banko valdybos nutarimai. v) İmonių restruktūrizavimo atveju kreditorių susirinkimas pritaria restruktūrizavimo plano projektui, jeigu už ji balsuoja kreditoriai, kurių reikalavimų suma vertine išraiška sudaro ne mažiau kaip $2 / 3$ visų teismo patvirtintų kreditorių reikalavimų sumos vertinès išraiškos, tuo tarpu banko restruktūrizavimo atveju kreditorių ir / ar akcininkų pritarimo apskritai nereikia, vietoj to egzistuoja banko gaivinimo ir pertvarkymo plano procedūra, kuri iš esmès pagrịsta išimtinai priežiūros institucijos sprendimais. Apibendrinant akivaizdu, jog valstybė, norédama kuo operatyviau ir efektyviau kovoti su nemokių bankų problemomis, kurios pasižymi tam tikrais ypatumais, privalo turèti efektyvias teisines konstrukcijas, leidžiančias išspręsti mokumo problemų turinčio banko problemas.

\subsection{Pagrindinès banko pertvarkymo sąlygos Lietuvoje}

Visų pirma, pagal Lietuvoje esantị teisinį reguliavimą iš esmès banko pertvarkymo teisiniai mechanizmai kartu yra ir finansinio stabilumo stiprinimo priemonès ${ }^{28}$. Konkrečiam bankui taikytinos viena ar kelios finansinio stabilumo stiprinimo priemonès, pasirenkamos atsižvelgiant ị Finansinio tvarumo ịstatyme ịtvirtintus principus ir kitas šio ịstatymo nuostatas: ị banko finansinę padètị ir veiklos perspektyvas, $\dot{i}$ situaciją Lietuvos Respublikos finansų sektoriuje ir pasaulio finansų rinkose, ị banko, kuriam taikytinos finansinio stabilumo stiprinimo priemonés, prašymą ir Lietuvos banko išvadą bei siūlymus dèl taikytinos finansinio stabilumo stiprinimo priemonės, ¡̇ informaciją, gautą iš Lietuvos banko, apie jo pagal kitus ịstatymus bankui taikytas ar taikomas priemones ${ }^{29}$. Banko pertvarkymo mechanizmų panaudojimo sąlygos tiesiogiai susijusios su konkretaus banko finansine būkle ir grèsmėmis, ypatingai akcentuotina galimas rizikos kilimas bankų sistemos stabilumui ir patikimumui.

Pirma ir bene svarbiausia banko pertvarkymo sąlyga - turi būti pateikta Lietuvos banko išvada, kad bankas turi likvidumo problemų arba kyla reali grèsmė, kad turès likvidumo problemų, ir Lietuvos banko pagal teisès aktus galimos taikyti priemonès yra nepakankamos banko likvidumo problemoms spręsti, arba yra išvada, kad kyla reali grèsmé, jog bankas taps nemokus ${ }^{30}$. Antra, igaliota priežiūros institucija, Lietuvos bankas, gali panaudoti tam tikrą mechanizmą turẻdama pagrindą daryti išvadą, 
kad netaikant šio įstatymo nustatytų finansinio stabilumo stiprinimo priemonių kils grèsmè bankų sistemos stabilumui ir patikimumui ${ }^{31}$. Trečia, pažymėtina ir tai, jog siekiant apsaugoti esamas banko nuosavybès teises, reikètų, kad banko pertvarkymo pradžios ir priežiūros institucijos intervencijos momentas būtų ankstyvojoje banko problemų sprendimų stadijoje. Tačiau sprendimas dèl restruktūrizavimo pradžios momento gali priklausyti nuo keleto kintamųjų ir veiksnių, susijusių su vyraujančiomis rinkos sąlygomis ar ypatingomis banko likvidumo, ar mokumo problemomis, o tai reiškia, kad reikalinga tam tikra priežiūros institucijos sprendimų prièmimo diskrecija. Tokią diskreciją Lietuvos bankui suteikia Lietuvos Respublikos Lietuvos banko įstatymas $^{32}$. Galiausiai, norint taikyti tam tikrą banko pertvarkymo teisini mechanizmą, labai svarbu ịvertinti visas faktines aplinkybes ir atsižvelgti $\underset{i}{i}$ tai, jog taikant pertvarkymo mechanizmą nebūtų pabloginama banko kreditorių, kurių reikalavimams netaikoma indèlių ir ísipareigojimų investuotojams draudimo sistema, turtinè padètis. Manytina, jog visais atvejais reikètų ịvertinti ir esamą, ir tą padètị, kurioje kreditoriai atsidurtų, jei nemokiam bankui šis mechanizmas nebūtų taikomas ir šis bankas įstatymų nustatyta tvarka būtų likviduojamas dèl bankroto. Kad galètų taikyti šias priemones, priežiūros institucijos pagal įstatymą turi turèti igaliojimus imti kontroliuoti žlugusią arba žlungančią ịstaigą, perimti akcininkų ir vadovų vaidmenị, perduoti turtą ir įsipareigojimus bei užtikrinti sutarčių vykdymą. Aptarus pagrindines banko pertvarkymo taikymo sąlygas ir su jomis susijusi teisinị reguliavimą kyla klausimas, kokie yra esminiai teisiniai mechanizmai, naudojami bankui susidūrus su mokumo problemomis pagal Lietuvos teisę? Kokia praktika Lietuvoje susiformavo taikant vieną ar kitą banko pertvarkymo teisinį mechanizmą? Kokios tokio pobūdžio restruktūrizavimo mechanizmų taikymo teisinès pasekmès?

\section{Banko veiklos apribojimas ir nacionalizavimas} AB banko „Snoras“ scenarijus

Tiriant teisinị reguliavimą Lietuvoje banko restruktūrizavimo teisinių mechanizmų kontekste akcentuotina, jog, kaip yra žinoma, visai neseniai du Lietuvos vietinio kapitalo bankai tapo nemokūs. Priežiūros institucijai reikejjo priimti tam tikrus sprendimus dèl teisinių mechanizmų panaudojimo ir (arba) tiesioginio banko likvidavimo (bankroto). Vienas iš banko pertvarkymo būdų yra banko nacionalizavimas. Iš esmès tai teisinis reiškinys, kai akcininkų valdymas pakeičiamas vyriausybès (tiksliau indèlių draudejo) valdymu. Pažymètina, kad Lietuvoje Vyriausybė turi teisę paimti banko akcijas visuomenès poreikiams ${ }^{33}$ tik išimtiniais atvejais, jei banko ak-

32 Lietuvos Respublikos banku ịstatymas, supra note 12, 8 straipsnis.

33 Lietuvos Respublikos finansinio tvarumo ịstatymo 8 straipsnio 6 dalis nustato, kad akcijų kainą tvirtina Vyriausybè, atsižvelgdama ị audito ịmonès ir (ar) turtą vertinančios ịmonès siūlymus, 
cijų paèmimas valstybės nuosavybėn yra būtinas tam, kad valstybė galètų laiku imtis veiksmų, reikalingų bankų sistemos stabilumui ir patikimumui užtikrinti, jei kitos galimos priemonès nèra tinkamos arba jau pritaikytų priemonių nepakanka šiam tikslui pasiekti. Banko akcijos visuomenès poreikiams paimamos Vyriausybès nutarimu teisingai atlyginant ${ }^{34}$. Nuosavybés teisé ị paimamas akcijas pereina valstybei nuo Vyriausybės nutarimo paimti banko akcijas visuomenès poreikiams ịsigaliojimo. Šis instrumentas yra daugiau kraštutinè teisinè priemonè, reikalaujanti didelių fiskalinių išlaidų (ypatingai tuo atveju, jeigu didžioji dalis banko kreditorių yra apdrausti), pasaulinejje praktikoje taikoma išimtiniais atvejais ${ }^{35}$. Kai akcijos yra paimamos visuomenés poreikiams pagal Lietuvos Respublikos finansinio tvarumo i̇statymą, akcininkai gali sprendimą skųsti, bet tik dalyje dèl teisingos kainos (kadangi ịstatyme numatyta išimtis iš bendrojo reglamentavimo, kad akcijos pereina valstybės nuosavybèn ne nuo atsiskaitymo momento, o nuo LRV nutarimo prièmimo). Pažymėtina, jog Lietuvoje akcijų paèmimas visuomenès poreikiams yra įmanomas ir kitų ịstatymų pagrindais. Akcijų paèmimas visuomenès poreikiams yra numatytas Indèlių ir įsipareigojimų investuotojams draudimo ịstatyme bei Bankų ịstatyme. Šiuose įstatymuose numatyti kiti nei Finansinio tvarumo ịstatyme paemimo pagrindai, nustatyta kita paėmimo procedūra. Pagal Indèlių ir ịsipareigojimų investuotojams draudimo ịstatymą VI „Indèlių ir ịsipareigojimų draudimas“ taryba, gavusi priežiūros institucijos informaciją, kad banko veikla néra saugi ir patikima ir kad bankas gali tapti nemokus, bei turèdama pakankamą pagrindą manyti, kad bankui galimas draudžiamas ịvykis gali kelti pavojų draudimo įmonès likvidumui ir tinkamam draudimo išmokų išmokejjimui, turi teisę priimti sprendimą paimti banko akcijas iš akcininkų. Pagrindinis akcijų paėmimo visuomenès poreikiams mechanizmo ypatumas šiuo atveju yra numatyta nuosavybès perẻjimo apskundimo galimybè.

Taigi, banko nacionalizavimas apima keletą esminių etapų. Visu pirma, bankas turi būti pripažintas nemokiu priežiūros institucijos sprendimu ${ }^{36}$, egzistuojantys tei-

o akcijų kainos nustatymo išlaidos apmokamos valstybès lèšomis. Nustatant banko akcijų kainą negali būti atsižvelgiama ị bankui pagal ši ịstatymą jau taikomas ar galimas taikyti finansinio stabilumo stiprinimo priemones. Buvusiems akcininkams sumokant nustatytą akcijų kainą už paimamas akcijas, jiems taip pat sumokamos Civilinio kodekso 6.210 straipsniol dalyje nustatyto dydžio palūkanos nuo jiems priklausančios sumokèti akcijų kainos už paimamas akcijas už laikotarpi nuo nutarimo paimti akcijas ịsigaliojimo dienos iki atsiskaitymo su buvusiais akcininkais dienos.

34 Lietuvos Respublikos finansinio tvarumo ịstatymas, supra note 10, 8 straipsnis.

35 Marinc, M.; Vlahu, R., supra note 8, p. 46.

36 Lietuvos banko valdybos $2012 \mathrm{~m}$. rugsèjo 7 d. nutarimas Nr. 132, „Dèl kredito ịstaigų nemokumo“. Kredito įstaigos nemokumas nustatomas pagal kredito įstaigos finansines ir priežiūrai skirtas ataskaitas, kitus iš kredito ịstaigos ar kitų asmenų gautus dokumentus ir (ar) prireikus atliekant kredito ịstaigos inspektavimą (tikrinimą). Lietuvos banko valdyba gali nuspręsti pripažinti kredito įstaigą nemokia, jeigu yra bent viena iš šių sąlygų: 1 . kredito įstaigos turto grynoji vertė yra mažesnè negu kredito ịstaigos ịsipareigojimai; 2. kredito įstaiga 6 mènesius iš 
sès aktai turi leisti priežiūros institucijai taikyti tam tikras poveikio priemones. Antra, valstybė turi turèti galimybę pagal esamą teisinę bazę rekapitalizuoti banką, t. y. užpildyti atsiradusią finansinę spragą. Tai vyksta išvalant neigiamą kapitalą ir valstybei innešant papildomą kapitalą bei iš esmès siekiant, kad bankas atitiktų priežiūros institucijos nustatytus kapitalo pakankamumo rodiklius.

Visai neseniai Lietuvos valstybė yra nacionalizavusi banką „Snoras“37. Toks sprendimas buvo priimtas vadovaujantis Bankų ịstatymo ir Finansinio tvarumo įstatymo nuostatomis, suteikiančiomis teisę išimtiniais atvejais, kai bankui gresia nemokumas, imtis atitinkamų poveikio priemonių, o jei jų nepakanka - paimti banko akcijas visuomenès poreikiams ${ }^{38}$. Prièmus tokị sprendimą apribojamos banko galimybès vykdyti prisiimtus įsipareigojimus. Bankas negali prisiimti naujų ịsipareigojimų, iš esmès banko veikla sustoja ir tai turi neigiamą ịtaką tokio banko klientams (preliminarieji susitarimai, sudaryti su šiuo banku iki nacionalizavimo, nèra vykdomi, bankinių paslaugų teikimo apribojimai sukelia nepatogumų klientams ir pan.) $)^{39}$.

Viena vertus, esant adekvačiam ir savalaikiam veiksmų koordinavimui nutarimas dèl banko nacionalizavimo pagal dabartinị teisiṇ̨ reguliavimą Lietuvoje gali būti priimtas labai operatyviai (tuo tarpu gali prireikti kelių mėnesių planavimo ir derybų kitoms ịstatymuose numatytoms restruktūrizavimo priemonėms pritaikyti), prièmus tokį nutarimą „sveiki“ skolinimo santykiai valstybejje išlaikomi, kreditoriai apsaugomi nuo dar didesnių nuostolių, viešas pasitikejjimas finansų sistema išlaikomas, mažeja galimybės sisteminei finansų sistemos rizikai. Todèl laiku pritaikius nacionalizavimo teisinị instrumentą tikètina, jog būtų išvengiama esminių pavèlavimų, susijusių su tiesioginiu didelio banko likvidavimu ir turinčių neigiamos ịtakos kreditoriams bei finansų stabilumui tolesniame banko bankroto procese. Sistemiškai vertinant banko nacionalizavimo teisinị mechanizmą, ịtvirtintą Lietuvos teisejje, manytina, jog vis dèlto banko nacionalizavimas apsaugo visus banko kreditorius nuo dar didesnių nuostolių nei tiesioginio likvidavimo procese. Ši priemonė padeda suvaldyti sistemines rizikas esant trapiam visuomenès pasitikejjimui bankų sistema. Nuo to mo-

eilès nevykdo Lietuvos banko valdybos nustatyto kapitalo pakankamumo (mokumo) normatyvo; 3. kredito ịstaiga per 5 darbo dienas negali ịvykdyti nors vieno kreditoriaus pagrịsto finansinio reikalavimo (dèl lèšų trūkumo kredito įstaigos sąskaitose negali atlikti kliento pavedimo, grąžinti indèlių ar kitų pasiskolintų lešų arba vykdyti kitų finansinių ịsipareigojimų).

37 Lietuvos banko ataskaita apie AB „Snoras“ bankroto procesą, supra note 24.

38 Lietuvos Respublikos banku įstatymas, supra note 12, 90 straipsnis.

39 Hoelscher, David S., supra note 7, p. 105. Tai ịprasta praktika ir tarptautiniu mastu. Pavyzdžiui, banko Continetal IIlinois National bank, JAV nemokumas. Tuo metu aštuntas pagal dydį šalies bankas buvo paskelbtas nemokiu. Užuot tiesiogiai likvidavus banką buvo priimtas nutarimas, kurio pagrindu Federaliné indèlių draudimo įmoné prisièmė $3 \mathrm{mlrd}$. JAV dolerių ịsipareigojimų ir perèmé nuosavybèn milijardo dolerių vertès blogų paskolų iš nemokaus banko. Valstybine įmone taip pat investavo pakankamai reikšmingą sumą grynųjų pinigų siekdama atstatyti kapitalo pakankamumo reikalavimus. Akcininkai nusileido ir atsisakẻ savo nuosavybès teisių dèl banko likutinès vertès bei pretenzijų ị turto masę, gautą likvidavus „blogą“ turtą. 
mento, kai bankas nusprendžia tęsti savo veiklą, mokūs klientai gali toliau išlaikyti kreditavimo-paskolinius teisinius santykius su banku. Tai ypatingai svarbu tuomet, kai valstybejje nèra alternatyvių kreditavimo šaltinių arba jie yra riboti ${ }^{40}$. Veiksmingai pritaikius šį instrumentą taip pat išvengiama esminių trikdžių bankinèje atsiskaitymų-mokéjimų sistemoje. Be to, laiku pritaikius ši mechanizmą nedidejja valstybès fiskalinès išlaidos. Kartu su nacionalizacija fiskalinès išlaidos yra ribojamos ta apimtimi, kuri reikalinga kapitalo lygiui pakelti ir palaikyti iki priežiūros institucijos nustatytos normos (atsiradusi spraga plius papildomas kapitalas) ${ }^{41}$. Kita vertus, reikia pamineti ir galimas neigiamas nacionalizavimo taikymo teisines pasekmes. Banko nacionalizavimas dažniausiai vis tiek paveikia finansų rinką, be to, neišsprendžia esminès problemos, t. y. iš esmès nenustato tikrųjų banko žlugimo priežasčių. Banko akcijas perèmus vyriausybei neįmanoma jų parduoti, be to, tai dažniausiai veda prie netiesioginių papildomų išlaidų, pavyzdžiui, skolinantis lèšas tarptautinèse rinkose ar papildomų teisminių ginčų dèl akcijų vertès. Kita su tuo susijusi teisinė problema teisès aktuose nèra nustatyta per kiek laiko už nusavintas akcijas turima atsiskaityti su akcininkais. Dar vienas esminis šio mechanizmo trūkumas yra tas, kad kai indèlininkai ir kiti banko kreditoriai žino, jog valstybé juos vis tiek apsaugos, net ir žlugus bankui, jie neturi priežasčių sekti su banko finansine veikla susijusių esminių i̇vykių, ìvairių banko finansinių ataskaitų, t. y. indèlininkai tampa nedisciplinuotais klientais. Toks reiškinys teisineje literatūroje apibūdinama „moral hazard ${ }^{\text {“42 }}$ (moralinè rizika) terminu. Kitas moralinis-teisinis aspektas bei su tuo susijusi rizika yra ta, kad kai valdymo organai žino "moral hazard“ principo ypatumus, jie gali imtis nepamatuotos ir pernelyg didelès rizikos (pvz., paskutinès vilties sprendimai) ir siekiant sprendimų igyvendinimo ex ante bandyti rekapitalizuoti banką. Be kita ko, nacionalizavimo atveju vyriausybė arba priežiūros institucija vis dèlto yra neefektyvi, nepatyrusi banko savininkè, neturinti specifinių žinių ir resursų (pvz., žmogiškųjų), todèl manytina, kad valdyti banką tinkamai ir efektyviai ji nesugebètų, be to, kyla ir politinè rizika, sprendimų priemimas nèra labai efektyvus ${ }^{43}$, atsiranda abejonių dèl informacijos gavimo būdų ir pagrindų tretiesiems asmenims, sprendimų greitis bei kokybe tampa iš dalies priklausomi ir nuo politinès valios. Taip pat pažymėtina, jog vadovaujantis Lietuvos Respublikos indèlių ir ịsipareigojimų investuotojams draudimo ịstatymu,

40 Hoelscher, David S., supra note 7, p. 109.

41 Ibid.

42 Hoelscher, David S., supra note 7, p. 106.

43 Sprendimą dèl finansinio stabilumo priemonès taikymo priima Vyriausybè. Finansų ministerija nagrinèja ir analizuoja gautą informaciją, nustato problemą, parenka konkrečią priemonę, nustato lešų šaltinius, rengia Vyriausybės nutarimo projektą. Lietuvos Respublikos Vyriausybẻ 2008 m. patvirtino Finansinių krizių prevencijos ir valdymo planą ir sudarẻ nuolatinę Finansinių krizių prevencijos ir valdymo komisiją. Visais atvejais informacija gali būtin nagrinejjama tiek Finansų ministerijoje, tiek Finansinių krizių prevencijos ir valdymo komisijoje, todèl manytina, jog tai per didelis asmenų ratas. 
fizinių ir juridinių asmenų indèliai iki 100 tūkst. eurų yra apdrausti. Tai reiškia, kad sustabdžius banko veiklą ar šiam bankui negalint ịvykdyti savo įsipareigojimų, bet kuriuo atveju visi asmenys, turintys šiame banke indèlius iki 100 tūkst. eurų, juos atgautų. Tačiau ta indèlių suma, kuri viršija 100 tūkst. eurų, yra neapdrausta ir lieka rizika, kad banko turimo turto nepakaks grąžinti šiuos indelius, juolab turint omenyje, jog teisminiai ginčai, siekiantys apsaugoti nuo nesąžiningų akcininkų veiksmų (ypatingai tais atvejais, kai vadovų ir savininkų veikla gali būti ne tik nesėkminga, bet ir įžūliai nusikalstama ar indèlininkų piniginès lěšos įkeistos už paskolas arba pervestos ị kitas galimai su akcininkais susijusias struktūras, lengvatinių mokesčių zonų jurisdikcijose ir t. t.) bei siekiantys „parpumpuoti“ turtą i banką ar pripažinti tam tikrus sandorius negaliojančiais trunka ilgai, o per tą laiką banko turtas gali nuvertèti ar pasidaryti nelikvidus.

\section{Banko turto, teisių, sandorių ir ịsipareigojimų perdavimas} (ang. purchase and assumption transactions) AB „Ūkio bankas“ scenarijus

Iš esmès banko turto, teisių, sandorių ir ịsipareigojimų perdavimas kitam bankui yra labiausiai paplitęs banko restruktūrizavimo teisinis mechanizmas pasaulinèje bankų nemokumo praktikoje $e^{44}$. Bendrąja prasme tai yra ir tam tikras turto atskyrimo mechanizmas, kurio tikslas - pertvarkymo institucijoms sudaryti salygas nuvertejusi arba problemini turta perduoti turto valdymo imonei, kad tas turtas būtų valdomas ir ilgainiui sutvarkytas. Turtas turètų būti perduodamas rinkos arba ilgalaike ekonomine verte, kad nuostoliai būtų pripažinti tuomet, kai įvykdomas perdavimas. Siekiant sumažinti konkurencijos iškraipymus ir moralinės rizikos pavojų, manytina, jog šią priemonę reikètų naudoti tik kartu su kitos rūšies pertvarkymo priemone. Banko, kuriam paskelbtas veiklos apribojimas (moratoriumas) ir paskirtas laikinasis administratorius, turtas, teisès, sandoriai ir įsipareigojimai gali būti perduodami kitam bankui, jeigu: 1) yra reali grèsmè, kad administruojamo banko turto grynoji vertė taps mažesnè negu banko įsipareigojimai ar bankas atitiks kitas priežiūros institucijos priimtuose teisès aktuose nustatytas sąlygas, kada bankas gali būti pripažįstamas nemokiu, arba nustatoma, kad bankas jau atitinka sąlygas, kada bankas gali būti pripažįstamas nemokiu, ir 2) administruojamo banko turto, teisių, sandorių ir įsipareigojimų perdavimas kitam bankui leistų išlaikyti indėlininkų pasitikèjimą bankų sistemos stabilumu ir patikimumu ir kitaip apsaugoti viešuosius interesus, o administruojamo banko likvidavimas dèl bankroto tokiu pačiu mastu neapsaugotų šių interesų $u^{45}$. Taigi, viso banko ar jo dalies perdavimo tikslas yra išlaikyti banką 
nenutraukusị ūkinès-komercinès veiklos išvengiant finansų sistemos "griaunančio efekto", kurị sukeltų tiesioginè banko likvidacija ar masinis indèlių atsiiminejjimas kituose bankuose. Pažymètina, jog viso banko ar jo dalies perleidimo sandorio struktūra yra gana paprasta: pirmiausia, reikalingas bankas, norintis ịsigyti gerąji finansini turtą iš žlugusio banko ir prisiimti indèlininkų įsipareigojimus, antra, indèlių draudikas arba Vyriausybe turi skirti piniginių lěšų (pvz., paskolos sandoris) kompensuoti skirtumą tarp gero banko turto ir prisiimtu įsipareigojimų ${ }^{46}$. Taigi banko turto, teisiu, sandoriu ir isipareigojimu perdavimo sandorio metu geras banko turtas yra perleidžiamas balansine (aktyvų) verte ir sandoryje nustatoma tenkinanti kompensacine įsipareigojimų suma. Tuo tarpu „blogai“ banko daliai skelbiamas bankrotas ir administratorius pinigines lèšas, realizavus blogą turtą, skirsto ịstatymų nustatyta tvarka pradejus veikti specialiam bankroto teisiniam reguliavimui. Tokio sandorio esme yra pagrịsta aukščiausios kainos principu (angl. the highest premium), t. y. laimi tas pirkèjas, kuris pasiūlo geriausią kainą, gauta priemoka sumažina pinigines lèšas, reikalingas gauti kompensuojant trūkumą, atsiradusị tarp perkamo turto vertės ir preziumuojamų ịsipareigojimų dydžio, skirtumas kompensuojamas Vyriausybès (indèlių draudimo sistemos).

Vadovaujantis Lietuvos Respublikos bankų ịstatymu administruojamo banko turto, teisių, sandorių ir ịsipareigojimų perdavimo metu gali būti perduodamas visas arba dalis administruojamo banko turto, teisių (turtinių ir neturtinių) ir sandorių bei visi arba dalis administruojamo banko ịsipareigojimų, tačiau: 1) visais atvejais turi būti perduodami administruojamo banko ịsipareigojimai Lietuvos Respublikos indèlių ir ịsipareigojimų investuotojams draudimo ịstatyme nurodytiems indèlininkams ir investuotojams, kuriems, esant draudžiamajam ịvykiui, būtų mokamos draudimo išmokos, neviršijančios sumos, kurią jiems privalètų išmokèti valstybės įmoné „Indèlių ir investicijų draudimas“, ir banko įsipareigojimai valstybės institucijoms ir įstaigoms, atsirandantys iš sandorių, sudarytu po banko veiklos apribojimo (moratoriumo) paskelbimo dienos; 2) neperduodami administruojamo banko ịsipareigojimai kreditoriams, kurių reikalavimai banko bankroto atveju tenkinami penktąja, šeštąja ir septintąja eile, t. y. pasitikètinès (subordinuotos) paskolos ir banko išleisti ne nuosavybès vertybiniai popieriai, kurie turi visus pasitikètinès (subordinuotos) paskolos požymius; banko akcininkų, banko stebėtojų tarybos narių, banko valdybos narių ir banko administracijos vadovų reikalavimai. Administruojamo banko turtas, teisès, sandoriai ir îsipareigojimai gali būti perduodami tik po to, kai jų vertinimą atlieka laikinojo administratoriaus pasitelkta audito įmonè ir (ar) turtą vertinanti imonè. Vykdant administruojamo banko turto, teisių, sandorių ir ịsipareigojimų perdavimą kitam bankui gali būti perduodamas iš karto visas numatytas perduoti turtas, teisès, sandoriai ir ịsipareigojimai arba perdavimas gali būti vykdomas dalimis. Be to, jau perduotas turtas, teisès, sandoriai ir ịsipareigojimai turto, teisių, sandorių ir ịsi- 
pareigojimų perdavimo dokumentuose numatytomis sąlygomis ir terminais gali būti grąžinami, esant reikalui atitinkamai tikslinant sumokètą verčių skirtumo padengimo sumą, administruojamam bankui, jeigu tokia galimybė aiškiai numatyta tokiuose dokumentuose arba paaiškèja aplinkybès, kad yra perduotas turtas, teisès, sandoriai ir ịsipareigojimai, kurių nebuvo numatyta perduoti. Reikia akcentuoti ir tai, jog turto atskyrimo mechanizmo taikymo atveju yra netaikomos Lietuvos Respublikos civilinio kodekso, kitų isstatymų ir teisės aktų ar banko sudarytų sandorių nuostatos, numatančios reikalavimus iš anksto kreditoriams, skolininkams ar kitiems asmenims pranešti apie tokius veiksmus, kurie atliekami vykdant turto, teisių, sandorių ir įsipareigojimų perdavimą, numatančios reikalavimus tokiems veiksmams atlikti gauti kitų asmenų leidimus ar sutikimus, įskaitant kreditoriaus sutikimą perkelti skolą kitam asmeniui, arba kitaip ribojančios turto, teisių, sandorių ir įsipareigojimų perdavimo vykdymą. Be to, turto, teisių, sandorių ir įsipareigojimų perdavimas nelaikomas sandorio pažeidimu ir (arba) teisèta priežastimi kreditoriams, skolininkams ar kitiems asmenims nutraukti sandorị, sudarytą su administruojamu banku. Tuo atveju, jeigu kreditoriai, skolininkai ar kiti asmenys, nesilaikydami šios nuostatos, nutraukia sandorị, toks sandoris gali būti grąžinamas atgal ị administruojamą banką ${ }^{47}$.

Iliustruojant ši pertvarkymo mechanizmą, reikia pažymėti, jog neseniai Lietuvos bankas AB „Ūkio bankas“ pripažino nemokiu ir visam laikui atšaukè jo veiklos licenciją ${ }^{48}$. Administruojamo banko turto, teisių, sandorių ir įsipareigojimų perdavimą priežiūros institucijos pritarimu bei atsižvelgdamas ị jos duotus nurodymus organizuoja ir vykdo laikinasis administratorius ${ }^{49}$, todel Lietuvos bankas igaliojo laikinąji administratorių pradèti derybas su kitais bankais dèl AB „Ūkio bankas“ ịsipareigojimų ir turto perdavimo kitam bankui. Iš viešai paskelbtos informacijos žiniasklaidos priemonèse galime teigti, jog buvo keturios pagrindinès banko gelbejjimo alternatyvos, kurias svarste laikinasis administratorius: banko rekapitalizavimas, laikinojo banko sukūrimas, banko bankrotas arba banko dalies turto, sandorių, teisių ir pareigu perdavimas. Remiantis tuo, kad banko turto, teisių, sandorių ir ịsipareigojimų perdavimas kitam bankui leistų labiau išlaikyti indèlininkų pasitikejjimą bankų sistemos stabilumu bei patikimumu ir kitaip apsaugoti viešuosius interesus nei $A B$ „Ūkio bankas“ likvidavimas dèl bankroto, Lietuvos bankas pasiūlè valstybès įmonei „Indèlių ir investicijų draudimas“ dalyvauti „Ūkio banko“ turto, teisių, sandorių ir ịsipareigojimų perdavimo finansavime pervedant lešas kitam bankui, kuris pagal LR bankų isstatymo 76 straipsnio nuostatas perème $\mathrm{AB}$ „Ūkio banko“ turtą, teises ir ịsipareigojimus tam, kad būtų padengta perduodamų ịsipareigojimų vertès ir kartu perduoda-

48 Lietuvos banko valdybos $2013 \mathrm{~m}$. vasario $18 \mathrm{~d}$. nutarimas Nr. 03-31 „Dèl AB „Ūkio bankas“ nemokumo“. [interaktyvus]. [žiūrèta 2013-03-13]. <https://www.lb.lt/lietuvos_banko_valdybos_nutarimai?\&pg=9>.

Lietuvos Respublikos bankų îstatymas, supra note 12, 76 straipsnio 4 dalis. 
mo turto, teisių ir sandorių vertès skirtumo suma, kuri, $\mathrm{AB}$ „Ūkio bankas“ laikinojo administratoriaus vertinimu, sudare $800 \mathrm{mln}$. litų ${ }^{50}$. Pažymètina, kad vadovaujantis Lietuvos Respublikos indèlių ir įsipareigojimų investuotojams draudimo įstatymu draudžiamasis ịvykis laikomas ịvykusiu, kai bankas negali atsiskaityti su kreditoriais, t. y. tampa nemokus ${ }^{51}$. Taigi sprendimas buvo grịstas logika, jog banko padalinimo atveju būtų užtikrinamas mokèjimo ir dalies kitų finansinių paslaugų teikimo žlungančio banko klientams tęstinumas, labiau, nei realizuojant visą $A B$ "Ūkio banko" turtą bankroto procedūros metu, būtų išsaugota žlungančio banko vertė. „Gerojoje“ dalyje liko kokybiškas banko turtas ir banko ịsipareigojimai. Tai reiškia, kad priemus tokį sprendimą banko indèlininkai ir kreditoriai liko apsaugoti, nes toks valstybès žingsnis leido išvengti banko nemokumo dèl ịsipareigojimų už „blogąji “ turtą. Vis dèlto nemokaus banko klientų reikalavimai, susiję su „blogojo“ banko dalimi, galètu likti nepatenkinti, kadangi kreditorių reikalavimai būtų vykdomi tik iš tų lěšų, kurios būtų gautos realizavus „blogajị “ turtą. Priežiūros institucija naudojo šị sandorị perkeliant tiktai pirminę dalị nemokaus banko ị laikinąji banką (angl. bridge bank), o vèliau parduodant laikinąji banką privačiam rinkos pirkejjui, kuriam perkeliamos pagrindinès banko paslaugos, ir atitinkamai likviduojama likusi pradinė banko dalis.

Viena vertus, išgryninant šio mechanizmo taikymo teisines pasekmes akcentuotina, jog taikant šį teisinị mechanizmą patiriamos mažesnès administravimo išlaidos. Šis metodas ypatingai taikytinas tuomet, kai bankas finansuojamas daugiausia iš indèlininkų ịneštų piniginių lèšų. Manytina, kad, priimant sprendimą dèl nemokaus banko problemų sprendimo ir tolesnio likimo, bene svarbiausios praktikoje yra operacinès rizikos problemos ${ }^{52}$. Viena iš teigiamų sandorio pasekmių yra ta, kad toks sandoris gali būti atliktas labai greitai (pvz., JAV buvo atvejų, kai tokio pobūdžio sandoris buvo atliktas ir jam pasiruošta per savaitgali ${ }^{53}$, Lietuvoje sandoris buvo sudarytas praejus 11 dienų po paskelbimo apie $\mathrm{AB}$ „Ūkio bankas" moratoriumą). Operatyvumas yra svarbus faktorius siekiant išlaikyti visuomenès pasitikẻjimą finansų sistema. Be to, tokio sandorio struktūrą lengva paaiškinti visuomenei, indèlininkams, t. y. iš esmès sandoris jiems nesukelia jokių neigiamų teisinių pasekmių išskyrus tai, jog jų sąskaitos yra perkeliamos ị naują banką. Jeigu yra keletas potencialių pirkejjų, toks sandoris leidžia vyriausybei ir / arba indèlių draudejjui, siekiant maksimaliai patenkinti kreditorių ir valstybės interesus, pritraukti maksimalią tokio sandorio kainą ir gauti maksimalią vertę už banko valdomą turtą. Tai padeda sumažinti reikšmingas fiskalines išlaidas, kurios dažniausiai būna skubaus vykdymo. Be kita ko, igyvendi-

$50 \mathrm{AB}$,Ūkio bankas“ laikinojo administratoriaus pateikta vieša informacija [interakyvus]. [žiūrèta 2013-03-13]. <http://www.ub.lt/>.

51 Lietuvos Respublikos indèlių ir ịsipareigojimų investuotojams draudimo įstatymas. Valstybès žinios. 2002, Nr. 65-2635. 2 straipsnis.

52 Hoelscher, David S., supra note 7, p. 109.

53 Ibid. 
nant banko turto, teisių, sandorių ir įsipareigojimų perdavimą išvengiama „griaunančio" efekto (kas yra labiau tikètina tiesioginio likvidavimo atveju), pirmuosius nuostolius prisiima akcininkai, neefektyvus bankas pašalinamas iš finansų sistemos. Esamieji banko skolininkai tęsia paskolinius teisinius santykius su perkančiuoju banku, todèl egzistuoja minimalus mokejjimų sistemą "griaunantis“ efektas. Perkantis bankas perima nemokaus banko prievoles ir jo vaidmenị atsiskaitymų ir mokejjimų sistemoje. Perdavimo sutartis patraukli ir dèl joje nustatomų kreditorių teisių apsaugos mechanizmų, kuriuos sudaro preliminarus ir galutinis perleidžiamo turto vertès nustatymo mechanizmas, pavyzdžiui, perkančiojo banko pareiga grąžinti banko dalies igyto turto vertès skirtumą, jeigu ji padideja, ir perleidžiančio banko opciono teisè išpirkti dalị perduoto turto.

Kita vertus, taikant banko turto, teisių, sandorių ir ịsipareigojimų perdavimo mechanizmą galima identifikuoti ir neigiamų teisinių pasekmių. Vienas esminių sandorio trūkumų yra tas, kad visi nemokaus banko indèlininkai yra apsaugomi, iskaitant sudètingus atvejus ir / ar ginčytinus finansinius reikalavimus, kurie nèra apsaugoti indèlių draudimo sistemos (pvz., obligacijos ar indèlio sertifikatai), dèl to dalis indèlininkų gali patikèti, jog jeigu nemokaus banko problemos bus išspręstos tokiu būdu, finansų sistemos ir rinkos stabilumas ir patikimumas rinkoje sugrius. Tokio pobūdžio sandorius techniškai bei operacine prasme sudetingiau igyvendinti. Dar vienas iš galimų trūkumų tas, jog dažniausiai banko turtas, teisès, sandoriai ir ịsipareigojimai pagal sutarti yra perduodami kitam bankui vadovaujantis atliktu preliminariu turto vertinimu, kuris yra abejotinos teisinės galios ${ }^{54}$. Atlikus patikslintą (išsamų ir galutinị) turto vertinimą skirtumas yra pervedamas arba draudimui, arba kita sutartyje nustatyta tvarka, tačiau gali iškilti ịvairių su tuo susijusių teisinių problemų bei padidèti teisminių ginčių tikimybė. Be to, praktikoje gali susiklostyti situacija, kai nusipirkęs portfelị bankas ị kaupiamųjų indèlių sąskaitas pervestas pinigines lèšas gali bandyti grąžinti atgal tais atvejais, kai paaiškèja, jog indėlininkai buvusiame nemokiame banke sudarytų kaupiamųjų ar universaliųjų indèlių sąskaitas (užsitikrinant galimybę bet kada juos pildyti, taip laiminti iš sudètinių palūkanų efekto) pildè po to, kai buvo apribota banko veikla, pavyzdžiui, paskirtas banko moratoriumas. Natūralu, jog perèmęs turtą ir ịsipareigojimus bankas nebenori mokèti nemokaus banko pažadètų palūkanų, nes tokie indèliai gali nebeatitikti rinkos sąlygų. Jau nupirkęs ir perèmęs nemokaus banko îsipareigojimus pirkejjas gali svarstyti galimybę vienašališkai pakeisti indèlių sutarties sąlygas iš nemokaus banko perimtiems kaupia-

54 Pagal Turto ir verslo vertinimo pagrindų ịstatymą turto rinkos kaina nustatoma ịstatymo nustatyta tvarka atliktoje turto vertinimo ataskaitoje, o „preliminaraus turto vertinimo“ teisinis statusas ịstatyme nenumatytas (Turto ir verslo vertinimo pagrindų ịstatymo 23 str.). Dažnai pateiktos turto preliminaraus ịvertinimo pažymos neatitinka Turto ir verslo vertinimo pagrindų ịstatymo 23 straipsnyje galutinei turto vertinimo ataskaitai nustatytų reikalavimų, todèl nèra pagrindo vadovautis šiame dokumente nurodyta turto verte (Turto ir verslo vertinimo pagrindų îstatymo 24 str. $1 \mathrm{~d}$.). 
miesiems indèliams ir svarstyti galimybę tokio pobūdžio indèlius apskritai perkelti ì "blogąją" nemokaus banko dalị arba šiems indèliams ịvesti naują mokestị. Dèl to iškyla didelè tikimybė, jog dalis buvusių nemokaus banko indèlininkų dèl portfeli peremusio banko veiksmų gali kreiptis ị teismą ir ginti savo teises. Be to, tokių sandorių tikslas yra lyg ir viešųjų tikslų tenkinimas (užtikrinti indèlininkų pasitikèjimą bankų sistemos stabilumu ir patikimumu ir apsaugoti viešuosius interesus), tačiau vien priežiūros institucijos dalyvavimas tokiuose sandoriuose savaime neleidžia teigti, kad užtikrinama viešojo ir privataus intereso pusiausvyra ir kad banko kreditorių teisès negali būti pažeistos.

Aptartas banko pertvarkymo teisinis mechanizmas literatūroje dar kartais yra vadinamas banko išskaidymu ị "gerą" ir "blogą" banką. Tai iš esmès koreliuojantys reiškiniai. Praktikoje dažnai atsitinka taip, jog, bankui jau turint mokumo problemų, po priežiūros institucijos įspèjimų pašalinti trūkumus, esminè banko valdomo turto vertẻ vis dèlto būna neaiški. Tokiu atveju priežiūros institucija gali priimti sprendimą padalinti nemokų banką ị dvi dalis - „gerąji“ banko turtą ir apdraustus indèlininkus laikydama pagrindiniame "gerame banke“ (angl. bridge bank) ir palikdama "blogą“" turtą ir neapdraustus banko įsipareigojimus „blogame“ banke. Tokiu atveju „laikinasis bankas" (angl. bridge bank) tampa skaidresnis ir gali būti nedelsiant parduodamas privačiam subjektui, tuo tarpu „blogas“ bankas likviduojamas, kas ir buvo padaryta $\mathrm{AB}$ „Ükio bankas" atveju. Akcentuotina, jog tapęs nemokus didelis, svarbią vietą rinkoje užimantis bankas ịprastai valdo didelị portfelị „blogų“ paskolų. Taigi, išskaidant nemokų banką $\mathfrak{i}$ "gerą" ir "blogą" minimizuojamos sisteminès finansų sistemos "griovimo" rizikos, kurios ịprastai kyla, kai nemokus tampa didelis rinkoje veikiantis bankas. Pagrindiné tokio banko pertvarkymo nauda yra ta, kad tai leidžia "geram“ bankui išimtinai susikoncentruoti ị verslą, nebereikia skirti resursų „blogų“ paskolų valdymui ir tiesioginèm likvidavimo procedūrom.

\section{Kai kurie kiti banko pertvarkymo teisiniai mechanizmai}

4.1. Banko verslo pardavimas (angl. mergers and acquisitions). Bendrąja prasme verslo pardavimo mechanizmas - tai pertvarkymo institucijos vykdomas kredito įstaigos, atitinkančios restruktūrizavimo sąlygas, nuosavybės priemonių arba turto, teisių ar įsipareigojimų perdavimas pirkèjui. Bankas reorganizuojamas, pertvarkomas ir likviduojamas Civilinio kodekso, Bankų ịstatymo, Finansų ịstaigų ịstatymo ir Akcinių bendrovių įstatymo nustatyta tvarka ${ }^{55}$. Jeigu finansinių sunkumų turintis bankas yra nemokus arba jam gresia nemokumas, priežiūros institucija, pagal vyraujančią tarptautinę praktiką, paprastai prieš priimdama sprendimą dẻl banko nemokumo stengiasi surasti pirkẻją, paprastai kitą finansų įstaigą, tikintis, jog pirkè- 
jas įsigys banką kaip visumą, t. y. parduoti banką kaip veikiantį verslą. Taikydamos verslo pardavimo priemonę ir bankui esant nemokiam, pertvarkymo institucijos gali komercinemis sąlygomis parduoti įstaigą arba visą, arba dalį jos verslo nereikalaudamos akcininkų sutikimo arba nesilaikydamos procedūrinių reikalavimų, kurie galiotų kitais atvejais. Tokiu atveju perkantis bankas gauna ne tik visą finansinių sunkumų turinčio banko turtą ir ịsipareigojimus, bet ir tampa juridinio asmens savininku. Techniškai banko ịsigijimas gali ịvykti perleidžiant finansinių sunkumų turinčio banko akcijas perkančiajam bankui (tiesioginis susijungimas) arba ikuriant naują banką kontroliuojančią bendrovę (holdingas), kuri kontroliuotų abu bankus ${ }^{56}$. Tokiu atveju pagal egzistuojantị teisinị reguliavimą Lietuvoje priežiūros institucija turi teisę skubiai parduoti finansinių sunkumų turintị banką. Jeigu bankas būtų uždarytas dèl nemokumo, automatiškai banko turto ir įsipareigojimų skaidrumas būtų abejotinas ir atitinkamai surasti norinti pirkti banką taip pat būtų sudètinga ${ }^{57}$. Be to, pati valstybė gali išpirkti finansinių sunkumų turinčio banko turtą, suderinus su konkrečiu banku pirkimo-pardavimo sąlygas ir kainą ${ }^{58}$. Reikia pažymėti, jog Lietuvoje banko turtas gali būti išperkamas tik tuo atveju, jei Lietuvos bankas pateikia išvadą, kad šios finansinio stabilumo stiprinimo priemonès panaudojimas leistų atkurti riziką ribojančių normatyvų vykdymą ar kitaip sustiprintų banko stabilumą ir patikimumą. Taigi, verslo pardavimo priemonè turètų sudaryti sąlygas valdžios institucijoms parduoti kreditų ịstaigą ar jos veiklos dalis vienam ar daugiau pirkèjų be akcininkų sutikimo. Taikydamos verslo pardavimo priemonę, valdžios institucijos tą ịstaigą arba jos veiklos dalis turètų pateikti rinkai atvirai, skaidriai ir nediskriminuodamos, kartu siekdamos kiek įmanoma pakelti pardavimo kainą, nesuteikti pirmenybės atskiriems potencialiems pirkèjams, vengti interesų konfliktų.

4.2. Laikinasis bankas. Iš esmès laikinasis bankas yra juridinis asmuo, kuris visas priklauso vienai ar daugiau viešųjų institucijų (tarp kurių gali būti pertvarkymo institucija) ir kuris sukuriamas tam, kad perimtų visą ar tam tikrą pertvarkomos kredito įstaigos turtą, teises ir ịsipareigojimus, kad teiktų visas arba tam tikras jos paslaugas ir vykdytų visą arba tam tikrą jos veiklą. Paminètina, jog Lietuvos bankas Lietuvoje veikiantiems bankams susidūrus su mokumo problemomis svarstė ir laikinojo banko ịsteigimo opciją. Pagal dabartini teisinị reguliavimą ${ }^{59}$ Lietuvos banko leidimas issteigti laikinąji banką nėra reikalingas, tačiau laikinasis bankas turi gauti licenciją, o Lietuvos bankui palikta teisè nustatyti ne ilgesnị kaip 3 mènesių terminą, per kurị laikinasis bankas privalo ịvykdyti visus leidimui ịsteigti banką ir banko licencijai gauti nustatytus reikalavimus ${ }^{60}$. Laikinasis bankas gali būti įsteigtas tuo atveju, kai Lietuvos

56 Marinc, M.; Vlahu, R., supra note 8, p. 44.

57 Supra note 1, 3 straipsnis.

58 Ibid., 6 straipsnis.

59 Supra note $1, .7$ straipsnis.

60 Ibid. 
bankas pateikia išvadą, kad ịsteigti laikinąjị banką būtina tam, kad laikinajam bankui galètų būti perduoti banko, dèl kurio finansinès būklès kyla grèsmė bankų sistemos stabilumui ir patikimumui, turtas, teisès, sandoriai ir ịsipareigojimai ${ }^{61}$. Reikia pažymèti, jog laikinojo banko pagrindinis tikslas yra jo vèlesnis pardavimas, įmanomas arba parduodant laikinojo banko akcijas, arba perduodant laikinojo banko turtą, teises, sandorius ir ịsipareigojimus vadovaujantis Lietuvos Respublikos bankų įstatymu. Nors laikinojo banko steigimas galètų būti greitas ir sklandus, šiam bankui reikètų perduoti nemokaus banko turtą, teises, sandorius ir ịsipareigojimus. Laikinas bankas perimtų "gerąją“ banko turto dalị, todèl valstybès lèšos būtų naudojamos ne tik steigiant laikinąjị banką ir įnešant lěšas ị kapitalą, bet ir perkeliant draustus ịsipareigojimus (kurių nepadengtų perduodamas turtas) indèlininkų atžvilgiu. Laikinas bankas turètų būti likviduojamas, jeigu jo niekas nenupirktų per dvejus metus (daugiausia terminą galima pratęsti iki 5 metų $)^{62}$. Tai reiškia, jog tokio mechanizmo sèkmingas igyvendinimas itin priklausytų nuo laikinojo banko galimybès gana trumpu laikotarpiu veikti pelningai. Priešingu atveju kyla pagrịstas klausimas, ar rinkoje atsirastų pirkejjas, norintis įsigyti laikinąji banką. Taikydamos laikinos įstaigos sukūrimo priemonę, pertvarkymo institucijos gali visą ar dalị ịstaigos verslo perduoti valstybès kontroliuojamam subjektui. Laikinos ịstaigos veikla yra laikina, o bendras tikslas tinkamomis rinkos sąlygomis verslą parduoti privačiajam sektoriui.

Apibendrindami galime teigti, jog užklupus finansų krizei Lietuvoje bankų sektoriaus ịstaigų turimas kapitalas ne visais atvejais buvo pakankamas tiek kiekybès, tiek kokybės požiūriu, todèl prireikè precedento neturinčios nacionalinių valdžios institucijų paramos bei atitinkamų banko pertvarkymo teisinių mechanizmų panaudojimo. Prieš taikant tiesioginio likvidavimo procedūras reikia atidžiai ịvertinti banko verslo pertvarkymo galimybes. Itin svarbu, kad priežiūros institucija vadovautųsi skaidrumo ir viešumo principais, kurie leistų užtikrinti visuomenès pasitikèjimą bankine sistema ir išvengti mokejjimų sistemos „irimo“, minimizuotų indèlininkų, vyriausybès, indèlių draudimo fondo nuostolius ir sumažintų neigiamas ekonomines pasekmes.

\section{Išvados}

Pagal dabartinį teisinị reguliavimą Lietuvoje nemokaus banko pertvarkymo teisiniai mechanizmai turètų būti suprantami kaip ịprastinès bankroto procedūros (likvidavimo) alternatyva ir kompleksinių tiek teismine, tiek neteismine tvarka vykdomų priemonių visuma, tam tikras banko restruktūrizavimo procesas, skirtas žlungančio banko sukeltoms problemoms spręsti. Atsižvelgiant ị bendrąji viešąji interesą

61 Lietuvos Respublikos bankų ịstatymas, supra note 12, 76 straipsnis.

62 Lietuvos Respublikos finansinio tvarumo ịstatymas, supra note 10, 7 straipsnis. 
(grèsmè finansiniam stabilumui, ypatingos svarbos banko funkcijos ir (arba) indèlių, klientų turto ir viešųjų lèšų saugumas), banko pertvarkymo teisinis mechanizmas turètų būti suprantamas ir kaip tam tikras teisinis procesas, skirtas banką restruktūrizuoti ir / arba likviduoti.

Likviduojant banką pagal ịprastinę bankroto procedūrą gali kilti pavojus finansiniam stabilumui, nutrūkti esminių paslaugų teikimas, todèl pritaikius tam tikrą banko pertvarkymo teisini mechanizmą ir tik tuomet likvidavus banką tikètina, jog būtų didesne apimtimi išsaugotas finansų sistemos stabilumas, užtikrintas esminių paslaugų teikimas, sumažinama viešoji finansinẻ parama.

Banko pertvarkymo teisiniai mechanizmai turètų būti taikomi, kai banko negalima likviduoti keliant ịprastinę bankroto bylą kartu nedestabilizuojant finansų sistemos ir kai reikia imtis priemonių, kad būtų sparčiai perduotos ir tęsiamos sistemiškai svarbios funkcijos, ir kai negalima pagrịstai tikètis alternatyvaus privataus sprendimo, įskaitant esamų akcininkų arba trečiojo asmens vykdomą kapitalo padidinimą, kuris būtų pakankamas visiškam ịstaigos gyvybingumui atkurti. Banko restruktūrizavimo mechanizmų panaudojimas turi užtikrinti mokejjimo ir dalies kitų finansinių paslaugų teikimo žlungančio banko klientams tęstinumą labiau nei realizuojant visą bankrutuojančio banko turtą bankroto procedūros metu. Svarbiausia yra tai, kad restruktūrizuojant banką būtų išsaugota žlungančio banko maksimali turto (aktyvų) vertè ir maksimaliai užtikrinami visų kreditorių interesai.

Laiku ir tinkamai pritaikius banko pertvarkymo teisinị mechanizmą atsiranda teigiamo socialinio poveikio galimybè: pirma, dèl to, kad mažinama sisteminès bankų sektoriaus krizès tikimybė ir saugoma nuo ekonominès gerovès nuosmukių po bankų sektoriaus krizių; ir, antra, dèl tinkamo banko restruktūrizavimo mechanizmo pritaikymo kiek įmanoma sumažinami dèl paramos kredito įstaigos nemokumo atveju mokesčių mokètojams tenkantys nuostoliai. Neadekvatus restruktūrizavimo modelio parinkimas gali sukelti vèlesniame etape (bankroto procese) daug teisinių problemų ir didelių nuostolių visoms suinteresuotoms šalims, pavyzdžiui, atitinkamai palaipsniui mažèja banko turto vertè.

Vienas pagrindinių banko pertvarkymo tikslų - užtikrinti teisinị tikrumą, tęstinumą, skaidrumą ir numatomumą, susijusį su požiūriu ị akcininkus bei banko kreditorius, ir išsaugoti maksimalią turto vertę, kuri kitu atveju neišvengiamai sumažètų bankroto atveju. Be to, banko restruktūrizavimo galimybė turètų skatinti neapsidraudusius kreditorius geriau įvertinti su jų investicijomis susijusią riziką bei daugiau domètis bankų teisine aplinka ir finansine veikla (sumažinti „moral hazard“ reiškinio pasekmes). 


\section{Literatūra}

Campbell, A. Bank insolvency and the problem of nonperforming loans. Journal of Banking regulation. UK, 2007.

Directive of the European Parliament and of the Council establishing a framework for the recovery and resolution of credit institutions and investment firms and amending Council Directives 77/91/EEC and 82/891/EC, Directives 2001/24/EC, 2002/47/EC, 2004/25/EC, 2005/56/ EC, 2007/36/EC and 2011/35/EC and Regulation (EU) No 1093/2010.

Europos Komisijos 2012 m. birželio 22 d. informacinis pranešimas. Briuselis, MEMO/12/478. 478 [interaktyvus]. [žiūrèta 2013-03-23]. <http://europa. eu/rapid/press-release_MEMO-12478_lt.htm\#PR_metaPressRelease_ bottom>.

Hoelscher, David S. Bank restructuring and resolution. New York: Palgrave Macmillan, 2006.

Hupkes, Eva H. G. The legal aspects of bank insolvency. A comparative analysis of Western Europe, the United States and Canada. Kluwer law international. 2000.

International monetary fund and the World bank report. April 17, 2009 "An overview of the legal, institutional, and regulatory framework for bank insolvency". VA, USA: World Bank Publications.

Lastra, R. M. Cross-border bank insolvency. New York: Oxford university press, 2011.

Lietuvos banko valdybos $2013 \mathrm{~m}$. vasario18 d. nutarimas Nr. 03-31. „Dèl AB
„Ūkio bankas“ nemokumo" [interaktyvus]. [žiūrèta 2013-03-13]. <https:// www.lb.lt/lietuvos_banko_valdybos_ nutarimai? \&pg=9>.

Lietuvos banko valdybos $2011 \mathrm{~m}$. lapkričio 16 d. nutarimas Nr. 03-186 „Dèl AB banko „Snoras“ veiklos apribojimo“. [interaktyvus]. [žiūrèta 2013-0313]. < https://www.lb.lt/lietuvos_banko_valdybos_nutarimai?\&pg=9>.

Lietuvos Aukščiausiojo Teismo 2012 m. vasario $20 \mathrm{~d}$. nutartis civilinèje byloje Nr. 3K-3-58/2012.

Lietuvos Respublikos finansinio tvarumo istatymas. Valstybès žinios. 2009, Nr. 93-3985.

Lietuvos Respublikos bankų îstatymas. Valstybès žinios. 2004, Nr. 54-1832.

Lietuvos Respublikos finansų ịstaigų istatymas. Valstybès žinios. 2002, Nr. 913891.

Lietuvos Respublikos indèlių ir issipareigojimų investuotojams draudimo ìstatymas. Valstybès žinios. 2002, Nr. 65-2635.

Marinc, M.; Vlahu, R. The Economics of Bank Bankruptcy law. Berlynas: Springer - Verlag Berlin Heidelberg, 2012.

Proposal for a regulation of the European Parliament and of the Council establishing uniform rules and a uniform procedure for the resolution of credit institutions and certain investment firms in the framework of a Single Resolution Mechanism and a Single.

Vilniaus apygardos teismo $2011 \mathrm{~m}$. gruodžio $12 \mathrm{~d}$. nutartis civilineje byloje Nr. B2-7791-611/2011. 
Anotacija. Straipsnyje nagrinëjama banko pertvarkymo teisine kategorija. Siekiama supažindinti su Lietuvos teisinejje sistemoje egzistuojančiais bankų pertvarkymo teisiniais mechanizmais, banko pertvarkymo teisiniu mechanizmu samprata. Analizuojami šiu mechanizmu pagrindiniai principai ir tikslai, aptariamos pagrindines banko pertvarkymo salygos, atskleidžiamos pagrindinès teisinès pasekmès, kylančios pritaikius tam tikrą teisini mechanizmą.

Reikšminiai žodžiai: banko nemokumas, banko likvidavimas, banko pertvarkymas, banko pertvarkymo teisiniai mechanizmai, finansu krizé.

\title{
BANK RESOLUTION MECHANISMS ACCORDING TO LITHUANIAN CASE STUDY
}

\author{
Tomas Ambrasas
}

Mykolas Romeris University, Lithuania

Summary. Recently, the banking industry has faced considerable challenges in Lithuania. Two banks faced insolvency almost in a year's time. These cases subsequently have undergone dramatic changes in society, which now has a new legal viewpoint. Resolution and the bail-out of failing banks have an impact on the perceived credit risk as well as the financial soundness and the solvency of banks. Besides, they lead to many legal issues, which should be investigated at a scientific level. Regarding bank insolvency proceedings, essentially there are two options: direct liquidation (bank bankruptcy) or bank resolution (different legal techniques of restructuring). The main objective of bank restructuring is to restore individual banks or their solvency, merge, sell, or recapitalize banks, recover assets, operations and procedures. On the other hand, the main objectives of bank liquidation are to reduce creditors' losses and to eliminate insolvent banks from the market under the regular insolvency procedures. The main objective of the paper is to analyze bank resolution methods from the perspective of Lithuanian law. Bank insolvency law is not analyzed and investigated essentially in the Lithuania's scientific field. Two issues are analyzed in this paper: legal options and legal mechanisms of bank resolution and, on top of that, effects of implementing bank resolution tools. Resolution tools are interconnected with recent Lithuanian bank insolvency cases and based on their practice. The main aim of the article is to analyze, investigate and expose bank resolution techniques according to the Lithuanian law system. The statements are derived from analyses of scientific literature, relevant legislation, practice of the courts and relevant reports. The paper is written from the perspective of Lithuanian law.

Keywords: bank resolution, bank liquidation, bank insolvency law, financial crisis. 
Tomas Ambrasas, Mykolo Romerio universiteto Teisès fakulteto Verslo teisès katedros lektorius ir doktorantas. Mokslinių tyrimų kryptis: banko nemokumo teisè (tiesioginio likvidavimo ir pertvarkymo procedūros).

Tomas Ambrasas, Mykolas Romeris University, Faculty of Law, Department of Business Law, lecturer and doctoral student. Research interests: bank insolvency law (liquidation and resolution procedures). 